\title{
Enterprising Women in Southern Africa: When Does Land Ownership Matter?
}

\author{
Zuzana Brixiová $^{1}$ (D) Thierry Kangoye ${ }^{2} \cdot$ Fiona Tregenna $^{3}$
}

Published online: 21 February 2020

(c) The Author(s) 2020, corrected publication 2020

\begin{abstract}
Limited access to finance remains one of the major barriers for women entrepreneurs in Africa. This paper presents a model of start-ups in which firms' sales and profits depend on their productivity and access to credit. However, due to the lack of collateral assets such as land, female entrepreneurs have more constrained access to credit than do men. Testing the model on data from the World Bank Enterprise Surveys in Eswatini, Lesotho, and Zimbabwe, we find land ownership to be important for female entrepreneurial performance in terms of sales levels. These results suggest that the small Southern African economies would benefit from removing obstacles to female land tenure and enabling financial institutions to lend against movable collateral. Although land ownership is linked with higher sales levels, it is less critical for sales growth and innovation where access to short term loans for working capital seems to be key.
\end{abstract}

Keywords Entrepreneurial sales $\cdot$ Innovation $\cdot$ Credit $\cdot$ Land $\cdot$ Gender $\cdot$ Africa

\section{Introduction}

Productive entrepreneurship and small, medium, and micro enterprises (SMMEs) can provide an essential possible source of growth and jobs for women outside of subsistence agriculture and the public sector in Sub-Saharan African economies (Amin 2010; Hallward-Driemeier 2013; Brixiová and Kangoye 2016). In a conducive policy environment, entrepreneurs and SMMEs also contribute to innovation, technology adoption, risk diversification, and even accessing foreign markets. For women, entrepreneurship can be an avenue to economic

Zuzana Brixiová

zuzana.brixiova@vse.cz

Thierry Kangoye

t.kangoye@afdb.org

Fiona Tregenna

ftregenna@uj.ac.za

1 University of Economics, Prague and VSB - Technical University of Ostrava, W. Churchill Sq. 1938/4, Žižkov, 13067 Prague 3, Czech Republic

2 African Development Bank Group, Avenue Joseph Anoma, 01, BP 1387, Abidjan 01, Côte d'Ivoire

3 DST/NRF South African Research Chair in Industrial Development, University of Johannesburg, 31 Henley Road, Auckland Park 2006, South Africa empowerment. Given the potential benefits they bring to society, entrepreneurship and SMMEs have received attention in global policy forums such as the G20. For example, the German G20 Presidency in 2017 identified female entrepreneurship as a growth driver, underscoring the importance of supporting women's access to credit and business networks, training, information services, and technical assistance.

Gender inequality, including in labor markets, and its links to growth and poverty reduction, is another area of heightened policy focus globally. International Monetary Fund research shows that the average annual GDP per capita growth in Sub-Saharan Africa (SSA) could be up to 0.9 percentage points higher if income and gender inequality were reduced to the levels observed in the fast-growing Southeast Asian economies (Hakura et al. 2016). Ostry et al. (2018) posit that improving gender diversity can result in larger economic gains than previously thought, due to benefits from diversity where men and women in the labor force are imperfect substitutes.

In African developing countries, where women face barriers to employment in the formal sector, productive entrepreneurship can be an avenue for escaping low-paid jobs in agriculture and reducing income gaps. While women-run small enterprises (including home-based businesses) are prevalent in the region and can help women escape from subsistence agriculture, Dieterich et al. (2016) show that the increase in per capita income is lower for small firms owned 
by women than for those owned by men. Determining which factors support or hinder women entrepreneurs and developing a conducive business environment for their start-ups and subsequent growth are vital for achieving sustainable job-intensive growth in Africa.

In this paper, which analyzed land ownership and access to credit as barriers to entrepreneurship, we drew conceptually on Lazaer (2005) who viewed entrepreneurship as a process of an efficient assembling of key factors of production (human, physical, and information resources). Empirically, we therefore defined entrepreneurs as owners of micro or small firms (with 10 people or less), since in such firms the owners are either also the managers or work closely with them. Against this background, the paper contributed to the literature on links between gender gaps in land ownership, access to finance and entrepreneurial performance in three Southern African economies: Eswatini, Lesotho, and Zimbabwe. ${ }^{1}$ While there has been considerable research on access to credit as a critical constraint to women's entrepreneurship, to the best of our knowledge, no such studies have been completed for small Southern African economies following the commodity price shock of 2015. In the aftermath of the price collapse, several countries in the region experienced tightened liquidity in the banking sectors and slower growth of private-sector credit, making this topic highly relevant.

Our analysis centered on women's access to land and, relatedly, their access to credit. This is a key issue, since the availability of land, and the associated access to finance with land as collateral, are considered critical for entrepreneurial performance in Africa. Towards this goal, the paper presented a model in which the size of the firm reflects both its productivity and access to credit which in turn depends on collateral. Due to the lack of collateral assets such as land, women's access to credit is more constrained than that of men, reducing productivity and the size of women-owned and women-managed firms.

Empirical testing of the model using 2016 World Bank Enterprise Surveys of Eswatini, Lesotho and Zimbabwe confirmed the importance of land ownership, for firm performance. To address potential endogeneity between land ownership and entrepreneurial outcomes, variability in

\footnotetext{
${ }^{1}$ In the most recently available figures, female unemployment stood at $24.4 \%$ in Eswatini, $14.9 \%$ in Zimbabwe and $38.8 \%$ in Lesotho according to national estimates as reported in World Bank World Development Indicators, see https://data.worldbank. org/indic ator/SL.UEM.TOTL.FE.NE.ZS ?most_recent_value_ desc $=$ true \&view $=$ chart. In all three cases, the rates of female unemployment were higher than that of male unemployment. Female unemployment refers here to the percentage of the female labor force that is without work but available for and seeking employment; this measures women who are willing to work and who are actively seeking employment. It thus does not include women who choose not to work or who are not actively trying to obtain jobs.
}

firms' challenges in accessing land was used as an exogenous determinant of firms' land collateral. The empirical analysis also revealed factors other than access to land and credit that were associated with well-performing women's firms. In particular, while women-owned firms were less likely than firms owned by men to fund their activities with credit from formal sources, including through an overdraft facility, those that were part of a larger firm recorded better sales performance. With this analysis of the firm's business linkages, our research also contributes to the literature on the role of social and professional networks in the performance of women-run firms (Brixiová and Kangoye 2019; Renzulli et al. 2000).

To sum up, this paper contributes to literature on land ownership and performance of women entrepreneurs in Southern Africa, a topic which has so far received limited attention. Specifically, the paper examined whether women's curtailed access to land, and hence to credit from formal financial institutions, was linked to a weaker performance among women-run firms in the region. The analysis indicated that improving access to credit and the property rights framework are vital for supporting female entrepreneurship at a larger scale. At the same time, while land ownership (as collateral) matters for sales performance of women entrepreneurs operating larger firms, it is less important for micro and small firms trying to grow and innovate.

The rest of the paper is organized as follows. After this introduction, we present a review of the literature and the theoretical model followed by a description of the data and the basic facts, as well as a discussion of the empirical results. We end with a conclusion of our findings.

\section{Review of the Literature}

Evidence suggests that access to finance is a potential key barrier to entrepreneurial start-ups and performance (Fig. 1). Access to credit for SMMEs in both developing and developed countries has been studied extensively and continues to be of interest, given the persistence of this challenge. Earlier research on the topic includes $\mathrm{Li}$ (1998) on advanced economies, Brixiová and Kiyotaki (1997) on transition economies, Aghion et al. (2007) on selected OECD advanced and emerging markets, and Baliamoune-Lutz et al. (2011) on Africa. More recently, Fowowe (2017) examined subjective measures of financing access in 30 African countries and found that financing was key for firm growth. Quartey et al. (2017) showed that access to finance by SMEs in West Africa was affected by firm size, formality, ownership, strength of legal rights, depth of credit information, managerial experience and firms' export orientation.

Although access by women entrepreneurs to funding has been well studied, research on the financial constraints of 
Fig. 1 Access to finance as a constraint to entrepreneurship in developing countries: a New firm entry and cost of start-ups. b New firm entry and difficulty of getting credit. Source: Authors' calculations based on the World Bank Doing Business and Entrepreneurship database. Note: Cost of start-ups includes all official fees and fees for professional services if such services are required by law
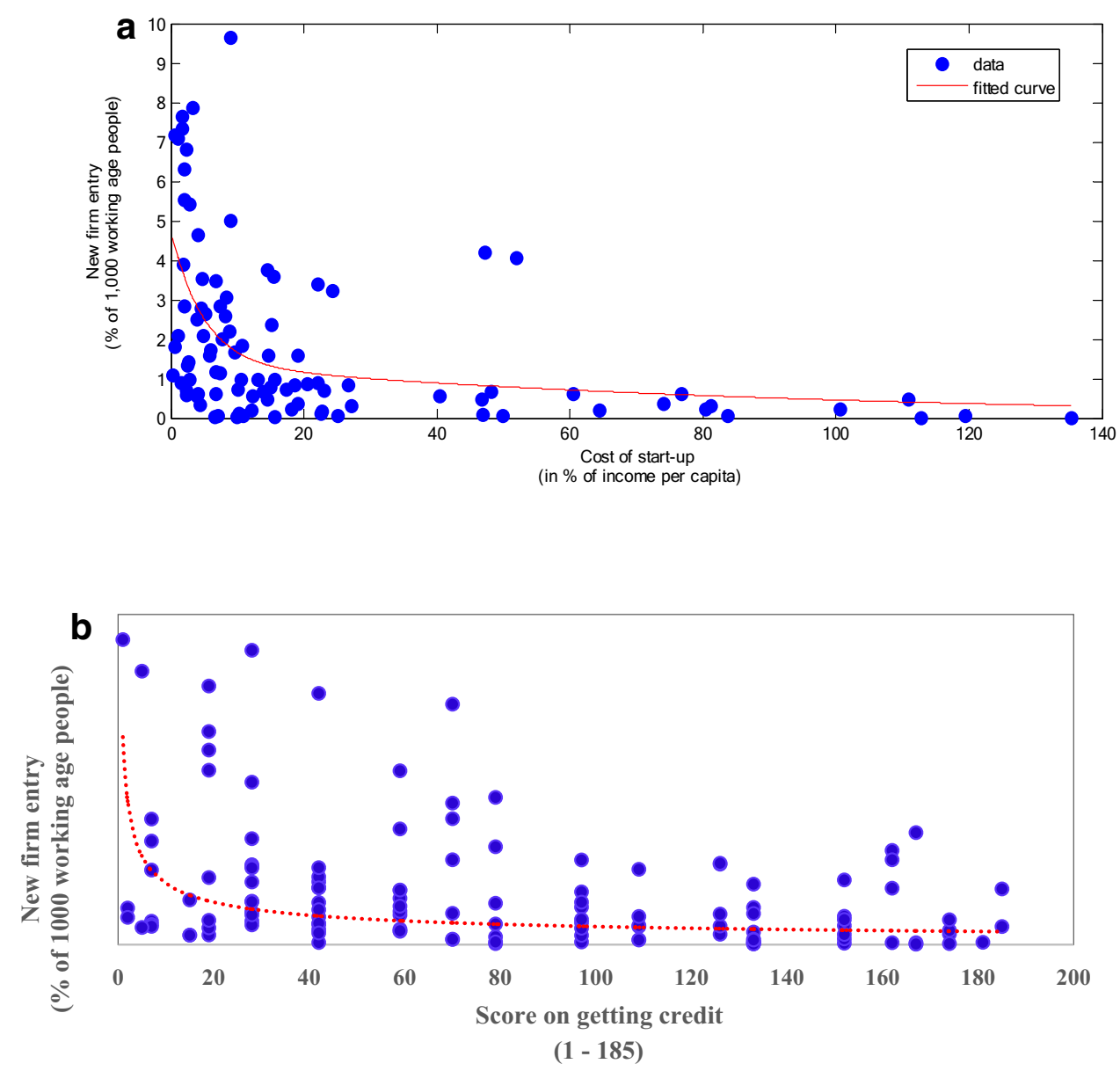

women-led firms in African countries has been relatively sparse. Exceptions include Asiedu et al. (2013), who empirically examined gender gaps in access to finance by firms in Africa and across developing regions. According to the authors, the gender of the firm's owner was an important determinant of financing constraints for SMEs, especially in SSA. Drawing on cross-sectional financial data from firms in the Middle East and Africa from 2006 to 2014, Baliamoune-Lutz and Lutz (2017) found that first, the availability of equity and/or debt capital and the higher leverage had significant and positive effects on firm performance and second, that firms owned by women had lower levels of equity and debt capital and lower leverage. However, they found evidence that when female-owned firms acquired more financing, their improvement in performance exceeded that of other firms, pointing to access to finance as a binding constraint on performance.

Several earlier studies on developing and emerging market countries also found gender differences in the amount and composition of start-up capital, with women facing greater constraints than men (Malapit 2012; Nieman and Nieuwenhuizen 2014). Women entrepreneurs face challenges in accessing formal sources of funding during the start-up phase and end up drawing on their personal sources or borrowing in the informal financial sector. For example, in a case study from South Africa, Derera et al. (2014) found evidence of various barriers faced by women specifically in raising start-up capital because of a number of genderdiscriminatory practices in lending. In their study in the Netherlands, Verheul and Thurik (2001) found gender gaps in the amount of start-up capital, but not in its composition (debt-to-equity ratios).

Regarding differences in entrepreneurs' attitudes towards risk, one stream of the literature posits that, relative to wage workers, entrepreneurs tend to be people with unusually low risk aversion (Kanbur 1980, 1982; Kihlstrom and Laffont 1979). Subsequently, the level and structure of startup capital in SMEs reflects the owners' more tolerant attitudes towards risk. Singh and Belwal (2008) extended this argument and suggested that gender differences in start-up capital are linked to variances in risk appetite, in addition to differences in the entrepreneur's experience of running a firm and in the nature and type of the business. Another stream of the literature stresses that risk attitude is not the key determinant of entrepreneurship, but rather that motivation and capabilities are key factors (Baumol 1990; Kirzner 
1973; Knight 1921). Accordingly, only some segments of the population have interest in the aptitude to become opportunity-driven entrepreneurs, that is, are able and interested to effectively seize business opportunities. In the analysis below, we build on this second stream and focus on differences in resources and skills in explaining gender differences in firm performance. This approach is also in line with more recent research that argues that gender differences in risk attitudes are smaller than previously thought, and that contextual influences contribute importantly to such differences (Nelson 2015).

Although the focus of this paper is on land ownership and access to finance as obstacles to entrepreneurship in developing African countries, we considered other factors for the gender differences in entrepreneurial performance. This approach draws on the three perspectives on entrepreneurship used by social scientists. The first perspective examines the personal characteristics of the entrepreneurs, including different skills and attitudes between men and women towards entrepreneurship (Lazaer 2005). The second perspective emphasizes social factors such as cultural values and social networks (Kristiansen 2004; Renzulli et al. 2000), while the third perspective highlights the institutional environment (Aidis and Estrin 2014), including access to credit (Chaudhuri et al. 2019). ${ }^{2}$

\section{The Model}

The economy consists of a large number of entrepreneurs who live for one period and have the population size normalized to 1 , and of a large number of lenders who also live for one period. Initially, all entrepreneurs are endowed with $A>0$ units of a consumption good that can also be used as collateral and is uniformly distributed between $O$ and $A$. Entrepreneurs have risk-neutral preferences in consumption, $c$, which depends on the profit, $\pi$, from running a firm, or on consuming the collateral $A$ and income $y_{i}$ from activities in the informal sector. At the beginning of the period, entrepreneurs decide whether to open their own firms or remain engaged in subsistence activities in the informal sector. Consumption takes place at the end of the period.

When opening a firm, entrepreneurs pay start-up costs equal to $\gamma$ units of the consumption good; $\gamma>0$. An entrepreneur with collateral $A$ can borrow up to $b \leq \theta A$, where $\theta \in(0,1)$, which is the share of collateral that the

\footnotetext{
${ }^{2}$ Djankov et al. (2005) provide an overview of the three perspectives in Russia. Mordi et al. (2010) found that women's access to loans from formal financial institutions in developing countries is hampered by a lack of credit history, limited collateral and unfavorable institutional arrangements.
}

lender can recover. This reflects the strength of the financial sector. $^{3}$

More specifically, while the endowment of the single $\operatorname{good} A$ can be used for both consumption and investment in the firm, the liquidation value of the capital for outsiders is smaller than for the entrepreneur. An alternative explanation is provided by transaction costs involved in recovering the collateral. For either reason, if the entrepreneur defaults on borrowing, the lenders can recover only $\theta$ proportion of the value of the capital. The creditors thus restrict lending to an entrepreneur $i$, at $b_{i}$, to an amount not exceeding the collateral value of the entrepreneur's assets. Entrepreneurs can open firms only if their borrowing capacity exceeds start-up cost, that is $\gamma \leq \theta A$. Hence, the cut-off level of the collateral that allows firm entry, $A^{*}$, is:

$\gamma / \theta=A^{*}$

In (1), the cut-off level $A *$ rises with higher start-up cost and falls with the level of financial market development.

An entrepreneur $i$ with collateral level of capital $A_{i}>A^{*}=\gamma / \theta$, who borrows $b_{i}$, can invest capital amounting to $k_{i}=A_{i}+b_{i}-\gamma$ in production and earn profit according to:

$\pi_{i}=z k_{i}-r b_{i}-\gamma=z\left(A_{i}+b_{i}-\gamma\right)-r b_{i}-\gamma$

where $\mathrm{z}>1$ denotes the productivity level and $r$ is the real interest (cost of borrowing), which each entrepreneur takes as given. From (2), it follows that, for an entrepreneur $i$, the profit $\pi_{i}$ needs to be above the subsistence-level income that it is possible to earn in the informal sector. Differently put, (2) shows that, as long as $\pi_{i}>y_{i}$, an entrepreneur $i$ with collateral level $A_{i}>A^{*}$ will decide to enter the consumption good sector and borrow (and invest) up to the limit set by $b_{i}=\theta A_{i}$, in which case the credit constraint is binding.

The profit is positively linked with productivity $z$, capital $k_{i}$, and hence borrowing $b_{i}$ (as long as $z>r$ ), which depends positively on the amount of entrepreneur's collateral, $A_{i}$, and the share that the creditors are willing to lend against, $\theta$. Profits are negatively linked to the real interest rate, $r$, and to the start-up cost, $\gamma$ :

$\pi_{i}\left[z_{(+)}, r_{(-)}, k_{i(+)}, \theta_{(+)}, A_{i(+)}, \gamma_{(-)}\right]=z\left(A_{i}+\theta A_{i}-\gamma\right)-r b_{i}-\gamma$

To sum up, the model suggests a positive relationship between firm profit and sales, access to credit (including entrepreneurs' collateral), and entrepreneur characteristics that would raise productivity, such as human capital (education and experience). It points to a positive link between

\footnotetext{
${ }^{3}$ The value of $\theta$ (share that can be recovered) depends positively upon the design and enforcement of private contracts and the development of the financial sector.
} 
entrepreneurial firm creation, productivity and conducive business regulations, such as the legal framework protecting investment or transparent and simple start-up procedures.

Hence, shortages of collateral for credit in the model slow down the rate of productive start-ups and reduce the average firm size. To the extent that land is the main source of collateral and women entrepreneurs own less land than men, they will have lower access to finance. They will also tend to operate in smaller-scale (subsistence) and less productive activities and record lower sales or profits on average. More female than male entrepreneurs are thus likely to end up operating in the informal sector. Below, we describe the test of the empirical links between land ownership, access to credit and firm performance (as measured by the volume of sales) using data from a World Bank survey of firms in Eswatini, Lesotho, and Zimbabwe, with a focus on gender differences. ${ }^{4}$

\section{Data and Descriptive Statistics}

To investigate how land ownership, access to finance and gender affect firm performance, we utilized data from the 2016 World Bank Enterprise Surveys (at firm level) in Eswatini, Lesotho and Zimbabwe. We focus on a total of 662 micro-, small and medium-sized enterprises in the manufacturing and service sectors with 10 employees or less; the firms have information about the female share in total ownership. ${ }^{5}$ The empirical analysis drew on the definition of an entrepreneur as an owner-manager, as discussed in, for example, Gartner (1990) and Lazaer (2005). The ownermanager approach to entrepreneurship is particularly pertinent in the analysis of credit constraints, where firm ownership and loan collateral are critical.

The key features of the micro-data used in our analysis are:

Firm-level data The data in this article used a firm as the unit of reference, with firm owners or top managers being the respondents. The survey sample frame was derived from all eligible firms provided by the country's statistical office.

Size threshold The firms were classified as follows: micro (fewer than five employees) and (very) small (five to 10 employees). Firms of such small size are likely to work in

\footnotetext{
$\overline{4}$ The model also has several limitations, key among them is its static nature, and hence it does not provide insights into how firm size and performance evolve over time. However, a one period model is consistent with the 2016 World Bank Enterprise survey of microenterprises in Zimbabwe, which is available for that year only.

${ }^{5}$ In all three countries, the data collectors used standardized survey instruments and sampling strategy to minimize measurement error and ensure that data were comparable across economies..
}

entrepreneurial teams, where the owner either is or works closely with the manager.

Industry classification Manufacturing and services were the primary sectors surveyed. Services included construction, retail, wholesale, hotels, restaurants, transport, storage, communications and information technology (IT).

The World Bank Enterprise Survey questionnaires included both objective and subjective questions about the business environment, and about the firms' and entrepreneurs' characteristics. Subjective variables provided information on the perceptions of the surveyed firms and entrepreneurs regarding key constraints facing their business, while objective questions were designed to document the firms' characteristics and activities (legal status, structure of capital, sales, size, access to finance, sectors of activity, etc.), and also to quantify constraints such as number of power outages, number of days to get construction-related permits, delays in obtaining operating licenses, etc.

We took as the main proxy of firm performance sales performance, measured by the log of the total annual sales over the last fiscal year before the survey (2015 or 2015/2016). We examined the role of gender and asset ownership by including in the econometric model the gender of the owner, as well as an indication of whether or not s/he owned the land occupied by the business, which we assumed could serve as collateral for the loans. In the Enterprise Surveys, firms were asked about the share of their working capital financed through internal resources and financial institutions, and also if they currently had access to formal financial services in the form of overdraft facilities. Those variables were included as controls.

We also controlled for additional variables to address concerns about possible omitted variable bias and factored in the model the possible mechanisms through which gender and land ownership may affect sales performance. These included the size of the enterprises (measured by the number of employees), the sector in which the business operated (i.e. manufacturing vs. services), whether the firm was an exporter, whether it was part of a larger firm, and innovation (proxied by a binary variable taking the value of 1 if the firm recently introduced a new or significantly improved product or service to the market, and 0 otherwise). Several of these factors have already been considered to be important determinants of firms' performance (Sarder et al. 1997; Wengel and Rodriguez 2006; Wynarczyk and Watson 2005). Appendix provides further information on these controls.

As shown in Table 1, the surveyed firms exhibited large variation in key summary statistics across the countries in the sample. These variations included sales performance, the sources of finance for working capital, the share of female ownership and the presence of a woman as top manager, the perceptions of obstacles, and the size and age of the business. 
Table 1 Descriptive statistics for the key variables, whole sample

\begin{tabular}{|c|c|c|c|c|c|}
\hline Variable & No. of obs & Mean & SD & Min & Max \\
\hline \multicolumn{6}{|l|}{ Firms' performance } \\
\hline Sales in $2015 / 16$ (average, US\$ thousands) & 658 & 243.90 & 777.30 & 2 & 15,000 \\
\hline Labor productivity in $2015 / 16$ (average, US\$ thousands) & 658 & 47.10 & 119.20 & 1 & 1500 \\
\hline Sales growth during $2013-2016(\mathrm{Y}=1, \mathrm{~N}=0)$ & 551 & 0.31 & 0.46 & 0 & 1 \\
\hline Firm introduced innovative product/process $(\mathrm{Y}=1, \mathrm{~N}=0)$ & 662 & 0.19 & 0.39 & 0 & 1 \\
\hline \multicolumn{6}{|l|}{ Firms' gender characteristics } \\
\hline One of the firm's owners is female $(Y=1, N=0)$ & 662 & 0.36 & 0.48 & 0 & 1 \\
\hline Firm has top female manager $(Y=1, N=0)$ & 662 & 0.22 & 0.42 & 0 & 1 \\
\hline \multicolumn{6}{|l|}{ Firms' general characteristics } \\
\hline Size (number of employees) & 661 & 4.93 & 2.21 & 1 & 10 \\
\hline Ratio of temporary to full-time workers & 660 & 0.28 & 0.81 & 0 & 9 \\
\hline Sector experience of top manager (years) & 645 & 11.16 & 8.96 & 1 & 56 \\
\hline Firm is part of a large firm $(Y=1, N=0)$ & 662 & 0.24 & 0.427 & 0 & 1 \\
\hline Firm operates in manufacturing $(\mathrm{Y}=1, \mathrm{~N}=0)$ & 662 & 0.184 & 0.388 & 0 & 1 \\
\hline \multicolumn{6}{|l|}{ Perceived obstacles } \\
\hline Lack of skilled workers is obstacle $(\mathrm{Y}=1, \mathrm{~N}=0)$ & 658 & 0.506 & 0.500 & 0 & 1 \\
\hline Access to finance is an obstacle $(\mathrm{Y}=1, \mathrm{~N}=0)$ & 659 & 0.863 & 0.344 & 0 & 1 \\
\hline Lack of land ownership is obstacle $(\mathrm{Y}=1, \mathrm{~N}=0)$ & 657 & 0.586 & 0.493 & 0 & 1 \\
\hline \multicolumn{6}{|l|}{ Firms' land ownership and access to finance } \\
\hline Firm owns land occupied $(Y=1, N=0)$ & 653 & 0.277 & 0.448 & 0 & 1 \\
\hline Share of land ownership (\%) & 662 & 26.246 & 43.515 & 0 & 100 \\
\hline Firm has overdraft facility $(\mathrm{Y}=1, \mathrm{~N}=0)$ & 650 & 0.111 & 0.314 & 0 & 1 \\
\hline Share of internal funds in financing $(\%)$ & 653 & 77.68 & 35.39 & 0 & 100 \\
\hline Share of funds from local banks (\%) & 653 & 2.41 & 10.195 & 0 & 100 \\
\hline
\end{tabular}

Authors' calculations based on data from the World Bank Enterprise Surveys
For example, firms' sales ranged from less than US\$2000 to about US\$ 15 million, with a mean value of US\$ 243,900. Only less than one out of five of the firms in the sample operated in the manufacturing sector. The statistics pointed to the access to finance to be an important obstacle to entrepreneurial operations, with firms relying more on their internal resources than on banks to finance their working capital. The vast majority of firms did not have overdraft facilities. More than half of the firms analyzed also considered the lack of skilled workers to be an important impediment.

Regarding differences in the sales performance of firms based on the gender of the owner(s), Fig. 2a illustrates that sales by firms with male ownership only exceeded those of firms with some female ownership in the highest sales range. Firms in which the top manager was male outperformed female-managed firms throughout most of the sales ranges, including in the highest range (Fig. 2b). Moreover, the performance of male-managed and male-owned firms did not seem to be associated with the lowest sales ranges (Figs. 2a and b).

Table 2 summarizes gender differences, showing that, on average, micro and small firms with at least some female ownership recorded similar sales to those with only male ownership. Male entrepreneurs (owners) were more likely to own land, had a higher percentage of working capital funded by local banks, had a better access to an overdraft facility and were more likely to export their product than their female counterparts. Firms owned by men also more often reported a lack of skilled workers and land ownership as obstacles to their firms' performance. While not showing causality, the descriptive analysis in Table 2 points out some of the barriers that female-managed firms in our sample face. Of particular relevance to our analysis is the observation that male-owned firms are less constrained in access to finance than are femaleowned firms. We explore these issues further in the econometric analysis that follows.

It also needs to be underscored that among firms with 10 or less employees, firms with female owners posted comparable performance with that of firms owned by men. It is at a higher scale (among firms with up to 100 employees) where differences in sales and other measures of performance emerge, highlighting the importance of factors that enable women to operate at a larger scale.

\section{Empirical Results}

Building on the theoretical underpinning, we estimated the following equation: 


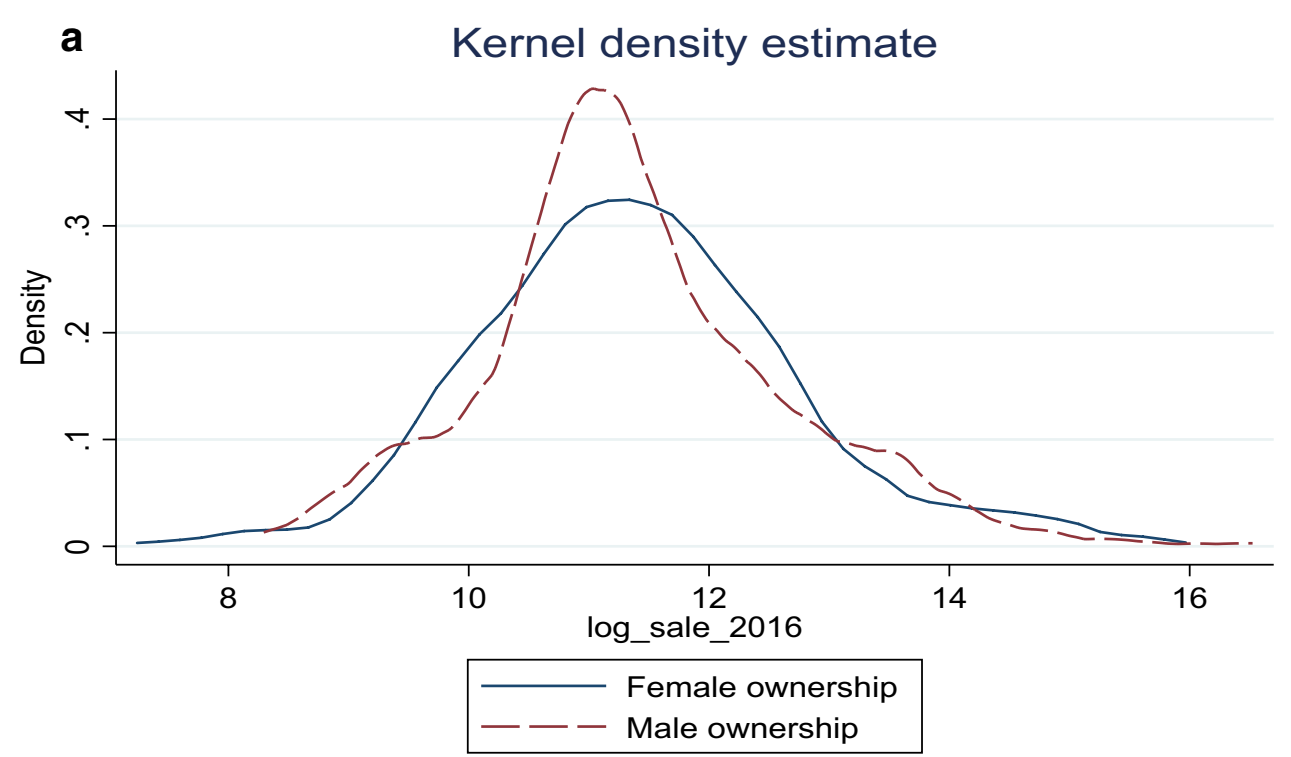

kernel $=$ epanechnikov, bandwidth $=0.3603$

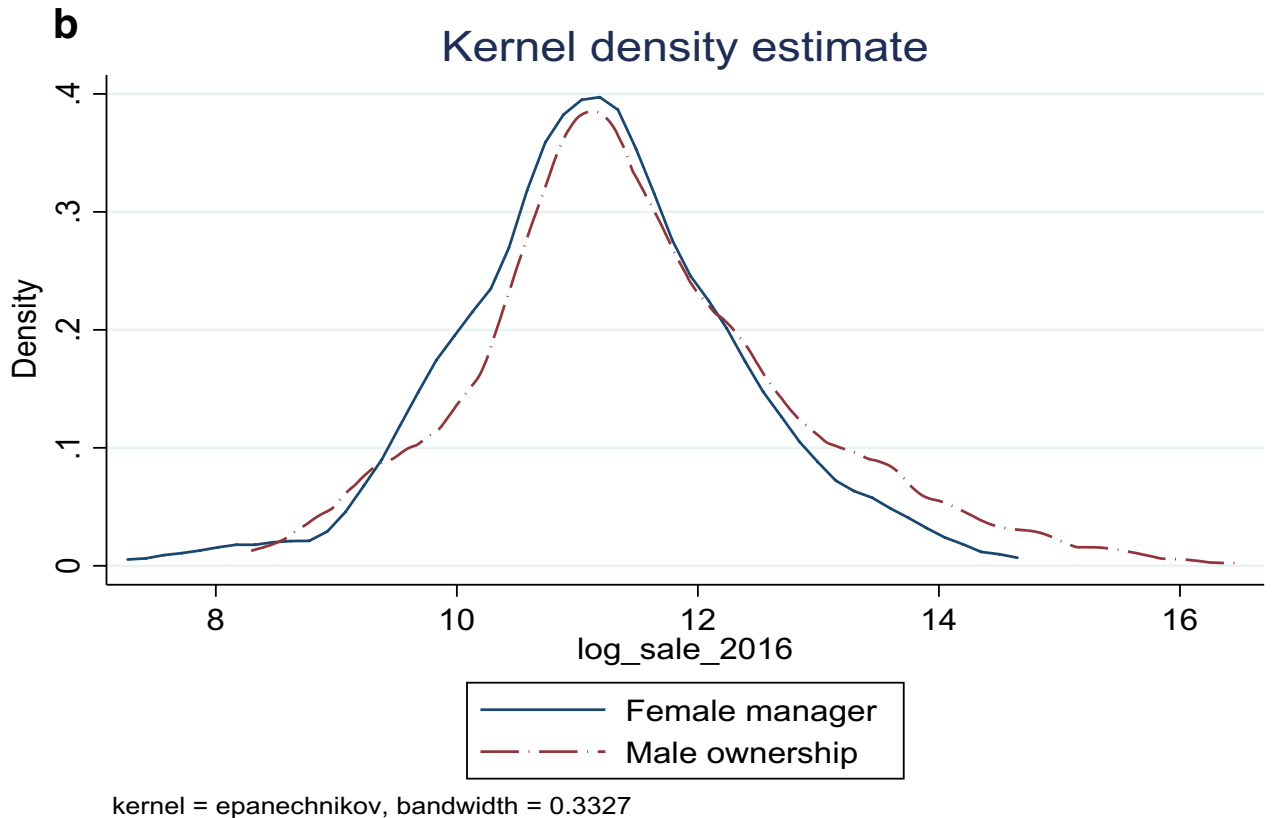

Fig. 2 a Distribution of sales in Eswatini, Lesotho, and Zimbabwe, by gender of the owner(s). Kernel density estimate of $\log$ of sales for firms with 10 or fewer permanent employees. b Distribution of sales in Eswatini, Lesotho, and Zimbabwe, by gender of the manager. Ker-

$$
\log \left(\text { sales }_{i}\right)=\alpha+\gamma \cdot \text { general business char }_{i}+\delta \text {.land ownership }_{i}
$$$$
+ \text { v.gender } r_{i}+\varepsilon_{i}
$$

where $i$ stands for individual firms, and the dependent variable (log of sales) is a logarithm of the amount of sales in the fiscal year prior to the survey (converted to US\$ at an average exchange rate). Table 3 summarizes the main regression results. Column 1 displays the results from the nel density estimate of log of sales for firms with 10 or fewer permanent employees. Source: Authors' estimates based on the World Bank Enterprise Surveys

baseline econometric specification, which were based on the Ordinary Least Squares (OLS) estimation method with Huber-White-robust standard errors.

Although having a female owner did not seem to impact directly entrepreneurial performance, having a female manager tended to negatively and significantly affect the level of sales in most specifications. This finding is suggestive of the numerous barriers facing female 
Table 2 Characteristics of firms, by ownership according to gender

\begin{tabular}{|c|c|c|}
\hline Variable & $\begin{array}{l}\text { Small firms with female ownership } \\
(\mathrm{N}=236)\end{array}$ & $\begin{array}{l}\text { Small firms without } \\
\text { female ownership } \\
(\mathrm{N}=426)\end{array}$ \\
\hline \multicolumn{3}{|l|}{ Firms' performance } \\
\hline Sales in $2015 / 16$ (average, US\$ thousands) & 245.2 & 243.2 \\
\hline Sales growth during $2013-2016(\mathrm{Y}=1, \mathrm{~N}=0)$ & 0.266 & 0.328 \\
\hline Firm introduced innovative product or process $(\mathrm{Y}=1, \mathrm{~N}=0)$ & 0.246 & 0.155 \\
\hline \multicolumn{3}{|l|}{ Firms' gender characteristics } \\
\hline Firm has top female manager $(Y=1, N=0)$ & 0.428 & 0.108 \\
\hline \multicolumn{3}{|l|}{ Firms' general characteristics } \\
\hline Size (\# of employees) & 4.97 & 4.91 \\
\hline Ratio of temporary to full-time workers & 0.377 & 0.227 \\
\hline Sector experience of top manager (years) & 12.9 & 10.16 \\
\hline Firm is part of a large firm $(Y=1, N=0)$ & 0.22 & 0.25 \\
\hline Firm operates in manufacturing $(\mathrm{Y}=1, \mathrm{~N}=0)$ & 0.191 & 0.181 \\
\hline \multicolumn{3}{|l|}{ Perceived obstacles } \\
\hline Lack of skilled workers is obstacle $(\mathrm{Y}=1, \mathrm{~N}=0)$ & 0.472 & 0.525 \\
\hline Access to finance is an obstacle $(\mathrm{Y}=1, \mathrm{~N}=0)$ & 0.859 & 0.866 \\
\hline Lack of land ownership is obstacle $(\mathrm{Y}=1, \mathrm{~N}=0)$ & 0.553 & 0.604 \\
\hline \multicolumn{3}{|l|}{ Firms' land ownership and access to finance } \\
\hline Firm owns land occupied $(\mathrm{Y}=1, \mathrm{~N}=0)$ & 0.264 & 0.284 \\
\hline Share of land ownership (\%) & 24.7 & 27.1 \\
\hline Firm has overdraft facility $(\mathrm{Y}=1, \mathrm{~N}=0)$ & 0.104 & 0.114 \\
\hline Share of working capital funded from internal resources (\%) & 77.8 & 77.61 \\
\hline Share of working capital funded by local banks (\%) & 2.07 & 2.59 \\
\hline
\end{tabular}

Authors' calculations based on data from the World Bank Enterprise Surveys

managers and entrepreneurs more broadly (in our sample). Although not tested empirically here (due to data limitations), we hypothesize that these barriers could include gendered differences in prior or contemporaneous access to relevant training and skills development. Perceptions that the lack of access to finance is an obstacle to operations were also negatively (and significantly) associated with lower sales.

In contrast, owning the land occupied by the firm, being part of a larger entity, and operating in the manufacturing sector seemed to be significantly associated with higher entrepreneurial sales. Both the size of the business and operating in the manufacturing sector were also positively associated with higher sales, as these factors also reflect the human capital in the enterprise and size of the labor force. Interestingly, we found that years of experience of the manager did not significantly affect sales performance.

Similarly, having overdraft facilities from financial institutions did not significantly affect firm productivity and neither did the entrepreneur's perceptions that the lack of skilled workers constitutes an obstacle, except for the specification (4). The mixed results on the extent to which an inadequately educated labor force is a constraint may reflect two different channels: on the one hand, this constraint could be expected to negatively affect their performance, as this appears to be the dominant effect in the manufacturing sector specifically; on the other hand, the presence of this constraint may be proxying more sophisticated firms that have higher skills requirements and hence experience this constraint more sharply, especially in the services sector.

To test the robustness of the findings with respect to the specification of the model, we included firm age and the indication whether it relied on temporary workers. To study country differences, we included dummy variables for firms in Eswatini and in Lesotho (i.e. with Zimbabwe as the base). Columns 2, 3 and 4 in Table 3 summarize the OLS results with this augmented specification.

Controlling for these variables in the main specification did not cause the estimated coefficients of gender of top manager and land ownership to change much in magnitude or statistical significance, suggesting that our results on these key variables are stable and robust to augmenting the model. Nevertheless, we found evidence that businesses that are older and rely on temporary workers tend to post 
Table 3 OLS and instrumental variable (IV) regressions of determinants of sales (log), whole sample

\begin{tabular}{|c|c|c|c|c|c|}
\hline & (1) & (2) & (3) & (4) & $(5)$ \\
\hline & OLS & OLS & OLS & OLS & IV \\
\hline \multirow[t]{2}{*}{ Firm has some female ownership $(\mathrm{Y}=1, \mathrm{~N}=0)$} & 0.152 & 0.063 & 0.057 & 0.024 & 0.114 \\
\hline & $(0.102)$ & $(0.104)$ & $(0.105)$ & $(0.102)$ & $(0.100)$ \\
\hline \multirow[t]{2}{*}{ Top manager is female $(\mathrm{Y}=1, \mathrm{~N}=0)$} & $-0.264 *$ & $-0.202 \dagger$ & $-0.191 \dagger$ & -0.087 & $-0.196 \dagger$ \\
\hline & $(0.108)$ & $(0.109)$ & $(0.110)$ & $(0.105)$ & $(0.116)$ \\
\hline \multirow[t]{2}{*}{ Lack of skilled labor is obstacle $(\mathrm{Y}=1, \mathrm{~N}=0)$} & 0.129 & 0.144 & 0.141 & $0.233 *$ & 0.111 \\
\hline & $(0.098)$ & $(0.098$ & $(0.100)$ & $(0.101)$ & $(0.100)$ \\
\hline \multirow[t]{2}{*}{ Firm operates in manufacturing $(\mathrm{Y}=1, \mathrm{~N}=0)$} & $0.429 *$ & $0.490 * *$ & $0.480 * *$ & $0.6^{* *}$ & $0.455^{*}$ \\
\hline & $(0.172)$ & $(0.176)$ & $(0.170)$ & $(0.157)$ & $(0.178)$ \\
\hline \multirow[t]{2}{*}{ Size (number of employees) } & $0.400 * *$ & $0.448 * *$ & $0.412 * *$ & $0.488 * *$ & $0.370 * *$ \\
\hline & $(0.106)$ & $(0.105)$ & $(0.106)$ & $(0.104)$ & $(0.109)$ \\
\hline \multirow[t]{2}{*}{ Size squared } & $-0.021 *$ & $-0.025^{* *}$ & $-0.022 * *$ & $-0.025 * *$ & $-0.019 * *$ \\
\hline & $(0.009)$ & $(0.009)$ & $(0.009)$ & $(0.009)$ & $(0.009)$ \\
\hline \multirow[t]{2}{*}{ Firm owns land it occupies $(Y=1, N=0)$} & $0.466^{* *}$ & $0.399 * *$ & $0.329 * *$ & $0.300 *$ & $0.947 *$ \\
\hline & $(0.111)$ & $(0.118)$ & $(0.125)$ & $(0.119)$ & $(0.478)$ \\
\hline \multirow[t]{2}{*}{ Currently has an overdraft facility $(\mathrm{Y}=1, \mathrm{~N}=0)$} & 0.025 & 0.032 & 0.048 & 0.121 & -0.005 \\
\hline & $(0.136)$ & $(0.137)$ & $(0.140)$ & $(0.129)$ & $(0.146)$ \\
\hline \multirow[t]{2}{*}{ Access to finance is an obstacle $(\mathrm{Y}=1, \mathrm{~N}=0)$} & $-0.225^{*}$ & $-0.280 *$ & $-0.307 * *$ & $-0.364 * *$ & -0.180 \\
\hline & $(0.114)$ & $(0.115)$ & $(0.118)$ & $(0.117)$ & $(0.146)$ \\
\hline \multirow[t]{2}{*}{ Business is part of a large firm $(\mathrm{Y}=1, \mathrm{~N}=0)$} & $0.691 * *$ & $0.706^{* *}$ & $0.647 * *$ & $0.615^{* *}$ & $0.675^{* *}$ \\
\hline & $(0.118)$ & $(0.120)$ & $(0.125)$ & $(0.124)$ & $(0.107)$ \\
\hline \multirow[t]{2}{*}{ Manufacturing * Lack of skilled labor } & $-0.530 *$ & $-0.572 *$ & $-0.549 *$ & $-0.381 \dagger$ & $-0.512 *$ \\
\hline & $(0.240)$ & $(0.244)$ & $(0.239)$ & $(0.216)$ & $(0.240)$ \\
\hline \multirow[t]{2}{*}{ Years of experience of top manager } & - & 0.006 & -0.002 & -0.002 & - \\
\hline & - & $(0.006)$ & $(0.007)$ & $(0.007)$ & - \\
\hline \multirow[t]{2}{*}{ Ratio of temporary to full- time workers } & - & $0.212 * *$ & $0.215^{* *}$ & $0.212 * *$ & $0.195 * *$ \\
\hline & - & $(0.061)$ & $(0.061)$ & $(0.061)$ & $(0.060)$ \\
\hline \multirow[t]{2}{*}{ Firm's age } & - & - & $0.011 *$ & $0.01 *$ & - \\
\hline & - & - & $(0.004)$ & $(0.004)$ & - \\
\hline \multirow[t]{2}{*}{ Eswatini dummy $(\mathrm{Y}=1, \mathrm{~N}=0)$} & - & - & - & $-1.118^{* *}$ & - \\
\hline & - & - & - & $(0.208)$ & - \\
\hline \multirow[t]{2}{*}{ Lesotho dummy $(\mathrm{Y}=1, \mathrm{~N}=0)$} & - & - & - & $-0.934 * *$ & - \\
\hline & - & - & - & $(0.183)$ & - \\
\hline \multirow[t]{2}{*}{ Constant } & $9.849 * *$ & $9.664 * *$ & $9.783 * *$ & $9.570 * *$ & $9.732 * *$ \\
\hline & $(0.282)$ & $(0.288)$ & $(0.289)$ & $(0.285)$ & $(0.279)$ \\
\hline Cragg-Donald Wald F-statistic & - & - & - & - & 29.15 \\
\hline $\mathrm{R}^{2}$ & 0.25 & 0.28 & 0.28 & 0.33 & 0.24 \\
\hline Number of observations & 635 & 618 & 601 & 601 & 632 \\
\hline
\end{tabular}

Note: Heteroskedasticity robust standard errors are in parentheses. $\dagger p<0.1 . * p<0.05$. $* * p<0.01$.

higher sales compared to younger firms and those relying only on permanent workers. In contrast, operating in either Eswatini or Lesotho was associated with a negative and statistically significant impact on sales level, which could be explained by the relatively more severe constraints to private sector development in these countries.

For robustness, we have also split our sample into firms with and without female ownership. The regression results (summarized in Table 4) are overall consistent with those in Table 3, and we have not found evidence of wide gender differences in factors driving sales performance. An exception is the presence of female manager, which has a negative and statistically significant impact on sales of femaleowned but not male-owned firms. Moreover, land ownership is associated with stronger positive impact on sales among female-owned than male-owned firms.

One important potential concern about the results is that, as firms grow, so does their capacity to purchase land, leading to a possible reverse causality between land ownership and firms' performance, and introducing endogeneity-related bias 
Table 4 OLS and instrumental variable (IV) regressions of determinants of sales performance by small firms in Eswatini, Lesoto and Zimbabwe, by gender

\begin{tabular}{|c|c|c|c|c|}
\hline & \multicolumn{2}{|l|}{ Women } & \multicolumn{2}{|l|}{ Men } \\
\hline & $(1)$ & $(2)$ & (3) & $(4)$ \\
\hline & OLS & IV & OLS & IV \\
\hline \multirow[t]{2}{*}{ Top manager is female $(\mathrm{Y}=1, \mathrm{~N}=0)$} & $-0.407 * *$ & $-0.418 *$ & 0.068 & 0.113 \\
\hline & $(0.148)$ & $(0.169)$ & $(0.156)$ & $(0.182)$ \\
\hline \multirow[t]{2}{*}{ Inadequately educated labor force is obstacle $(\mathrm{Y}=1, \mathrm{~N}=0)$} & $0.535^{* *}$ & $0.516^{* *}$ & -0.042 & -0.061 \\
\hline & $(0.165)$ & $(0.18)$ & $(0.124)$ & $(0.135)$ \\
\hline \multirow[t]{2}{*}{ Firm operates in manufacturing $(\mathrm{Y}=1, \mathrm{~N}=0)$} & $0.702 * *$ & $0.727 *$ & $0.431 \dagger$ & 0.399 \\
\hline & $(0.240)$ & $(0.310)$ & $(0.246)$ & $(0.245)$ \\
\hline \multirow[t]{2}{*}{ Size (number of employees) } & $0.393 * *$ & $0.376^{*}$ & $0.462 * *$ & $0.412^{*}$ \\
\hline & $(0.179)$ & $(0.176)$ & $(0.133)$ & $(0.177)$ \\
\hline \multirow[t]{2}{*}{ Size squared } & $-0.025 \dagger$ & $-0.025 \dagger$ & $-0.024 * *$ & -0.020 \\
\hline & $(0.016)$ & $(0.015)$ & $(0.011)$ & $(0.013)$ \\
\hline \multirow[t]{2}{*}{ Firm owns land it occupies $(\mathrm{Y}=1, \mathrm{~N}=0)$} & $0.558 * *$ & $1.968^{*}$ & $0.331^{*}$ & 0.584 \\
\hline & $(0.188)$ & $(0.894)$ & $(0.149)$ & $(0.868)$ \\
\hline \multirow[t]{2}{*}{ Currently has an overdraft facility $(\mathrm{Y}=1, \mathrm{~N}=0)$} & -0.099 & -0.197 & 0.070 & 0.079 \\
\hline & $(0.198)$ & $(0.284)$ & $(0.180)$ & $(0.184)$ \\
\hline \multirow[t]{2}{*}{ Access to finance is an obstacle $(Y=1, N=0)$} & -0.205 & -0.074 & $-0.291 *$ & -0.239 \\
\hline & $(0.201)$ & $(0.251)$ & $(0.145)$ & $(0.230)$ \\
\hline \multirow[t]{2}{*}{ Years of experience of top manager } & 0.014 & -0.002 & -0.002 & -0.005 \\
\hline & $(0.009)$ & $(0.013)$ & $(0.008)$ & $(0.011)$ \\
\hline \multirow[t]{2}{*}{ Business is part of a large firm $(\mathrm{Y}=1, \mathrm{~N}=0)$} & $0.964 * *$ & $0.823 * *$ & $0.540 * *$ & $0.536^{* *}$ \\
\hline & $(0.208)$ & $(0.219)$ & $(0.141)$ & $(0.136)$ \\
\hline \multirow[t]{2}{*}{ Manufacturing * Inadequately educated labor force is obstacle } & $-0.760^{*}$ & -0.522 & -0.508 & -0.488 \\
\hline & $(0.356)$ & $(0.449)$ & $(0.328)$ & $(0.303)$ \\
\hline \multirow[t]{2}{*}{ Ratio of temporary to full-time workers } & $0.168 * *$ & 0.132 & $0.249 *$ & 0.242 \\
\hline & $(0.064)$ & $(0.089)$ & $(0.103)$ & $(0.081)^{* *}$ \\
\hline \multirow[t]{2}{*}{ Constant } & $9.652 * *$ & $9.548 * *$ & 9.779 & 9.836 \\
\hline & $(0.516)$ & $(0.551)$ & $(0.359) * *$ & $(0.373)^{* *}$ \\
\hline Cragg-Donald Wald F-statistic & - & 10.34 & - & 8.83 \\
\hline $\mathrm{R}^{2}$ & 0.36 & 0.17 & 0.26 & 0.26 \\
\hline Number of observations & 222 & 222 & 396 & 394 \\
\hline
\end{tabular}

Dependent Variable is the Level of Sales (log)

Note: Heteroskedasticity robust standard errors are in parentheses. $\dagger p<0.1 . * p<0.05$. $* * p<0.01$.

in the findings. To address this concern, we re-estimated the results of column 1 in Table 3 and columns 2 and 4 in Table 4 using an instrumental variable (IV) approach. In this method, land ownership was instrumented by firms' perceptions of constraints on accessing land (proxied by a dummy variable taking the value of 1 if firms reported access to land as a moderate, major or severe obstacle to their current operations, and a value of 0 if they do not report it as an obstacle or reported it as a minor obstacle). It is reasonable to expect that having difficulties in accessing land would be a good and natural predictor of land ownership. Table 5, which present results from the first-stage regressions, shows that constraints on accessing land have a statistically significant and negative impact on land ownership. The Cragg-Donald F-statistic is above the rule-of-thumb value of 10 , leading us to reject the hypothesis of a weak instrument in the whole sample specification (column 5 of Table 3). The test is also met when applied to the female sub-sample in Table 4 (column 2). However, the Cragg-Donald criterion (Cragg and Donald 1993) was not met for the male sub-sample, leading us to interpret the estimated coefficient of the land ownership variable for this group more as an evidence of a positive correlation between access to land and performance of male-owned firms.

To sum up, the IV-based specification for all firms confirmed the main findings, with the land ownership coefficients now entering the regressions with a higher magnitude (and statistical significance) for the entire sample as well as for women only (column 2, Table 5). While operating in the 
Table 5 Probit first-stage regressions (dependent variable is land ownership—dummy variable talking the value of 1 if the entrepreneur owns the land occupied by the business, and 0 otherwise)

\begin{tabular}{|c|c|c|c|}
\hline & $\begin{array}{l}\text { All } \\
(1)\end{array}$ & $\begin{array}{l}\text { Women } \\
\text { (2) }\end{array}$ & $\begin{array}{l}\text { Men } \\
(3)\end{array}$ \\
\hline Access to land is an obstacle & $\begin{array}{l}-0.173 * * \\
(0.038)\end{array}$ & $\begin{array}{l}-0.201 * * \\
(0.063)\end{array}$ & $\begin{array}{l}-0.149 * * \\
(0.050)\end{array}$ \\
\hline Female ownership $(\mathrm{Y}=1, \mathrm{~N}=0)$ & $\begin{array}{l}-0.055 \\
(0.038)\end{array}$ & $\begin{array}{l}- \\
-\end{array}$ & - \\
\hline Top manager is female $(\mathrm{Y}=1, \mathrm{~N}=0)$ & $\begin{array}{l}0.009 \\
(0.044)\end{array}$ & $\begin{array}{l}0.015 \\
(0.059)\end{array}$ & $\begin{array}{l}-0.050 \\
(0.068)\end{array}$ \\
\hline Inadequately educated labor force is obstacle $(\mathrm{Y}=1, \mathrm{~N}=0)$ & $\begin{array}{l}0.080 * \\
(0.039)\end{array}$ & $\begin{array}{l}0.071 \\
(0.064)\end{array}$ & $\begin{array}{l}0.094 \dagger \\
(0.049)\end{array}$ \\
\hline Firm operates in manufacturing $(\mathrm{Y}=1, \mathrm{~N}=0)$ & $\begin{array}{l}0.038 \\
(0.068)\end{array}$ & $\begin{array}{l}-0.038 \\
(0.107)\end{array}$ & $\begin{array}{l}0.089 \\
(0.088)\end{array}$ \\
\hline Manufacturing ${ }^{*}$ Inadequately educated labor force is obstacle & $\begin{array}{l}-0.062 \\
(0.090)\end{array}$ & $\begin{array}{l}-0.104 \\
(0.149)\end{array}$ & $\begin{array}{l}-0.062 \\
(0.113)\end{array}$ \\
\hline Firm has an overdraft facility $(Y=1, N=0)$ & $\begin{array}{l}0.101 \\
-0.065\end{array}$ & $\begin{array}{l}0.072 \\
(0.097)\end{array}$ & $\begin{array}{l}0.057 \\
(0.068)\end{array}$ \\
\hline Size (number of employees) & $\begin{array}{l}0.094 * \\
(0.037)\end{array}$ & $\begin{array}{l}0.003 \\
(0.061)\end{array}$ & $\begin{array}{l}0.146 * * \\
(0.047)\end{array}$ \\
\hline Size squared & $\begin{array}{l}-0.006 \dagger \\
(0.003)\end{array}$ & $\begin{array}{l}0.002 \\
(0.005)\end{array}$ & $\begin{array}{l}-0.010^{*} \\
(0.004)\end{array}$ \\
\hline Access to finance is an obstacle $(Y=1, N=0)$ & $\begin{array}{l}-0.085 \dagger \\
(0.052)\end{array}$ & $\begin{array}{l}-0.035 \\
(0.084)\end{array}$ & $\begin{array}{l}-0.124 \dagger \\
(0.067)\end{array}$ \\
\hline Business is part of a large firm $(\mathrm{Y}=1, \mathrm{~N}=0)$ & $\begin{array}{l}0.110 * \\
(0.054)\end{array}$ & $\begin{array}{l}0.109 \\
(0.070)\end{array}$ & $\begin{array}{l}0.045 \\
(0.050)\end{array}$ \\
\hline Years of experience of manager & $\begin{array}{l}0.010 * * \\
(0.002)\end{array}$ & $\begin{array}{l}0.011 * * \\
(0.003)\end{array}$ & $\begin{array}{l}0.009 * * \\
(0.003)\end{array}$ \\
\hline Ratio of temporary to full-time workers & $\begin{array}{l}0.033 \\
(0.021)\end{array}$ & $\begin{array}{l}0.026 \\
(0.030)\end{array}$ & $\begin{array}{l}0.034 \\
(0.030)\end{array}$ \\
\hline Constant & $\begin{array}{l}-0.014 \\
(0.108)\end{array}$ & $\begin{array}{l}0.129 \\
(0.191)\end{array}$ & $\begin{array}{l}-0.123 \\
(0.135)\end{array}$ \\
\hline $\mathrm{R}^{2}$ & 0.136 & 0.138 & 0.131 \\
\hline $\mathrm{N}$ & 616 & 222 & 394 \\
\hline
\end{tabular}

$\dagger p<0.1{ }^{*} p<0.05$. $* * p<0.01$. manufacturing sector continued being significantly associated with higher sales levels, no significant interactive effect between the two variables was found in the IV-based specification. Whereas the access to finance lost statistical significance, the size of the business continued to be positively associated with higher sales. Finally, overdraft facilities from financial institutions did not seem to be good predictors of firm performance as evidence the negative but not statistically significant coefficient in the column 5 to Table 3.

In Table 6, we tested an alternative proxy of entrepreneurial performance, namely whether land ownership and access to finance remained significant for sales growth (if sales grew between 2013 and 2016) and innovation, in either production or process. ${ }^{6}$ Our main findings were that firms

\footnotetext{
${ }^{6}$ In this regard, we drew on the Schumpeterian definition of entrepreneurship as 'creating something new' (Schumpeter, 1934).
}

that perceived the access to finance to be an obstacle to their operations were less likely to record sales growth (columns 1-3), but, interestingly, more likely to innovate (columns 4 and 6). In contrast to sales level, neither land ownership nor gender of the manager were found to be significant for sales growth and innovation in any specification. Instead, for women entrepreneurs, ability to fund working capital, either through internal funds or local banks, was key only for posting rising sales. Moreover, and in contrast to the literature on temporary employment and innovation (Cetrulo et al. 2019), female-owned firms with more temporary workers were more likely to innovate. These finding indicate that while land ownership as collateral is key for the scale of the business, it is less critical for small firms' growth and innovation, where other factors such as working capital and 
Table 6 Probit regressions (dependent variable is growth of sales, taking the value of 1 if sales are growing and 0 otherwise and innovation, taking the value of 1 if yes and 0 otherwise)

\begin{tabular}{|c|c|c|c|c|c|c|}
\hline & (1) & (2) & (3) & (4) & $(5)$ & $(6)$ \\
\hline & $\begin{array}{l}\text { All-sales } \\
\text { growth }\end{array}$ & $\begin{array}{l}\text { Women-sales } \\
\text { growth }\end{array}$ & $\begin{array}{l}\text { Men-sales } \\
\text { growth }\end{array}$ & All-innovation & $\begin{array}{l}\text { Women-inno- } \\
\text { vation }\end{array}$ & $\begin{array}{l}\text { Men-inno- } \\
\text { vation }\end{array}$ \\
\hline \multirow[t]{2}{*}{ Top manager is female $(\mathrm{Y}=1, \mathrm{~N}=0)$} & -0.062 & -0.096 & 0.051 & -0.159 & -0.322 & 0.147 \\
\hline & $(0.156)$ & $(0.223)$ & $(0.232)$ & $(0.166)$ & $(0.214)$ & $(0.248)$ \\
\hline \multirow[t]{2}{*}{ Size (number of employees) } & -0.034 & -0.080 & -0.022 & $0.314^{*}$ & 0.244 & $0.375 \dagger$ \\
\hline & $(0.138)$ & $(0.244)$ & $(0.171)$ & $(0.154)$ & $(0.218)$ & $(0.218)$ \\
\hline \multirow[t]{2}{*}{ Size squared } & 0.003 & 0.003 & 0.003 & $-0.021 \dagger$ & -0.017 & -0.027 \\
\hline & $(0.011)$ & $(0.020)$ & $(0.014)$ & $(0.013)$ & $(0.018)$ & $(0.018)$ \\
\hline \multirow[t]{2}{*}{ Firm owns land it occupies $(\mathrm{Y}=1, \mathrm{~N}=0)$} & 0.138 & -0.015 & 0.243 & 0.077 & 0.168 & -0.006 \\
\hline & $(0.140)$ & $(0.253)$ & $(0.171)$ & $(0.141)$ & $(0.229)$ & $(0.184)$ \\
\hline \multirow[t]{2}{*}{ Currently has an overdraft facility $(\mathrm{Y}=1, \mathrm{~N}=0)$} & $-0.348 \dagger$ & -0.613 & -0.295 & 0.050 & 0.410 & -0.020 \\
\hline & $(0.203)$ & $(0.389)$ & $(0.240)$ & $(0.201)$ & $(0.334)$ & $(0.259)$ \\
\hline \multirow[t]{2}{*}{ Access to finance is an obstacle $(Y=1, N=0)$} & $-0.639 * *$ & $-0.839 * *$ & $-0.507^{*}$ & $0.565^{* *}$ & 0.222 & $0.866 * *$ \\
\hline & $(0.179)$ & $(0.304)$ & $(0.288)$ & $(0.204)$ & $(0.303)$ & $(0.322)$ \\
\hline \multirow[t]{2}{*}{ Years of experience of top manager } & $-0.024 * *$ & $-0.028 *$ & $-0.024 *$ & 0.008 & 0.017 & 0.000 \\
\hline & $(0.008)$ & $(0.012)$ & $(0.011)$ & $(0.007)$ & $(0.010)$ & $(0.011)$ \\
\hline \multirow[t]{2}{*}{ Business is part of a large firm $(\mathrm{Y}=1, \mathrm{~N}=0)$} & -0.133 & 0.050 & -0.199 & $0.316^{*}$ & 0.279 & $0.307 \dagger$ \\
\hline & $(0.145)$ & $(0.249)$ & $(0.178)$ & $(0.137)$ & $(0.236)$ & $(0.177)$ \\
\hline \multirow[t]{2}{*}{ Ratio of temporary to full-time workers } & $0.152 *$ & 0.147 & $0.191 \dagger$ & $0.253 * *$ & $0.498 * *$ & 0.121 \\
\hline & $(0.072)$ & $(0.112)$ & $(0.105)$ & $(0.074)$ & $(0.160)$ & $(0.099)$ \\
\hline \multirow[t]{2}{*}{$\%$ of working capital from internal funds } & $0.007 * *$ & $0.010 * *$ & $0.006 * *$ & 0.000 & 0.001 & 0.000 \\
\hline & $(0.002)$ & $(0.003)$ & $(0.002)$ & $(0.002)$ & $(0.003)$ & $(0.002)$ \\
\hline \multirow[t]{2}{*}{$\%$ of working capital from local banks } & $0.014 *$ & $0.039 * *$ & 0.007 & 0.002 & -0.002 & 0.005 \\
\hline & $(0.005)$ & $(0.012)$ & $(0.006)$ & $(0.006)$ & $(0.012)$ & $(0.007)$ \\
\hline \multirow[t]{2}{*}{ Firm has some female ownership $(\mathrm{Y}=1, \mathrm{~N}=0)$} & -0.159 & - & - & $0.332 *$ & - & - \\
\hline & $(0.139)$ & - & - & $(0.139)$ & - & - \\
\hline \multirow[t]{2}{*}{ Constant } & -0.083 & -0.091 & -0.235 & $-2.742 * *$ & $-2.183 * *$ & $-3.032 * *$ \\
\hline & $(0.424)$ & $(0.837)$ & $(0.505)$ & $(0.500)$ & $(0.772)$ & $(0.715)$ \\
\hline Pseudo $\mathrm{R}^{2}$ & 0.073 & 0.117 & 0.062 & 0.087 & 0.149 & 0.067 \\
\hline Number of observations & 518 & 191 & 327 & 617 & 220 & 397 \\
\hline
\end{tabular}

$\dagger p<0.1 .{ }^{*} p<0.05 . * * p<0.01$.

labor, seem to be key constraints. Differently put, while the lack of land ownership for collateral becomes an important obstacle to scaling up, other factors can drive performance of small-scale female entrepreneurs before this constraint becomes binding.

\section{Conclusions}

In this paper, we carried out analysis of linkages between land ownership, access to finance and female entrepreneurial performance. Our analysis consisted of two parts. In the theoretical part, we utilized a model applicable to credit markets in Southern Africa, where structural rigidities, including the lack of asset ownership such as land that can be pledged as collateral, impede firms' access to credit. This is especially important for understanding barriers to entrepreneurship. The model illustrates that, to the extent that female entrepreneurs (women-owned firms) are more constrained in accessing capital, they are likely to be less productive. In the empirical part, we tested the implications of the model on comparable firm surveys from Eswatini, Lesotho and Zimbabwe.

Broadly speaking, the analysis indicate that promoting access to credit and improving the property rights framework are vital for removing barriers to productive female entrepreneurship at a larger scale. Differently put, land as collateral matters more for women entrepreneurs operating mediumsized and large firms than small or micro firms. At the same time, taking a Schumpeterian view of entrepreneurship as creating something new, land ownership is less important for micro and small firms trying to grow and innovate.

More specifically, our findings have several policy implications. The results suggest that small Southern 
African economies could gain substantially from removing obstacles to female land tenure and ownership. This is of particular relevance to the three countries studied here, where women have restricted rights in land tenure and ownership. Our finding around access to land as a constraint on the sales (level) performance of micro and small firms in our sample has policy implications in the legislative domain around women's land rights.

Various policy options on enhancing access to land for female entrepreneurs in these three countries have been considered in the academic literatures and in policy discourse. We mention them without taking a prescriptive view as to which could be appropriate. One such measure is reforms that would enable banks and other financial institutions to lend against movable collateral. Weaknesses in legal systems that prevent lenders from fully recovering the pledged collateral could also be assessed, while taking into consideration the need to avoid discouraging the risk-taking that is important for productive entrepreneurship. The setting up, strengthening and regulating credit bureaus and institutions that collect information on business creditors and borrowers could also be relevant. Improving efficiency and capacity to analyze credit risks in the financial sector, in a way that does not explicitly or implicitly disadvantage female entrepreneurs, is also critical.

In addition to the complex process of land reform, our empirical results show that the governments and development partners can in parallel support other measures to foster productivity and innovation, in particular access to working capital and skills. Of particular relevance for the three countries analyzed in this paper is the role of effective development finance institutions (DFIs) to fill the financing gap facing micro, small and medium enterprises in general, and female entrepreneurs in particular. DFIs are well positioned to reduce the funding gap, given their ability to grant finance or provide the necessary guarantees to the financial sector, while considering a broader range of criteria with a higher tolerance of risk than banks, thus having possibility to support lending against low or no collateral.

Although our findings are not necessarily generalizable beyond the specific sample analyzed in this paper, there are possible implications for other developing countries. These are likely to be especially relevant in most closely comparable contexts, notably other Sub-Saharan African countries with patriarchal legal and/or socio-economic contexts and poor business environments (including credit constraints hampering entrepreneurship).

Finally, we note some limitations of our analysis. As discussed above, we only analyze micro and small firms from three small Southern African countries; further empirical research could extend this analysis to other countries and lager firms. While the number of firms in our sample is sufficient for statistical analysis, and is the maximum available for these countries from the data used, a larger sample could enhance the robustness of the results. An inherent limitation of this sort of empirical work is that not all variables that would preferably be included in a specification are available in the dataset employed, and thus care needs to be taken in interpreting results. Utilizing data from the World Bank Enterprise Surveys brings important advantages in terms of coverage and cross-country comparability, yet questionnaires are not as tailored to the interests of specific researchers as would be purposefully collected data. Another limitation is the cross-sectional nature of the analysis. Combining survey waves could strengthen our analysis of causality and offer insights in terms of changes over time. Similarly, the theoretical underpinning could be extended to a dynamic model to analyze the impact of changes in policies and institutions over time. We leave these areas for future research.

Acknowledgements The authors thank Mina Baliamoune, Mthuli Ncube, and Léonce Ndikumana for discussions on an earlier draft. Helpful insights were also provided by graduate students in the Applied Econometrics course at the Technical University of Ostrava. Earlier versions were presented at the 2016 Economic Research Southern Africa workshop (University of Cape Town), and at the 2018 Conference on Pathways to Gender Equality (American University, Washington DC). Zuzana Brixiová acknowledges funding from the Czech Science Foundation under Grant No. GA19 - 25280S. Fiona Tregenna acknowledges funding under the South African Research Chairs Initiative of the Department of Science and Technology and National Research Foundation of South Africa (Grant No. 98627). The views expressed are those of the authors and not necessarily those of the African Development Bank.

\section{Compliance with Ethical Standards}

Conflict of interest The authors declare that they have no conflict of interest.

Research Involving Human and Animal Rights This article does not contain any studies with human participants or animals performed by any of the authors.

Informed consent Informed consent was not needed for the study.

Open Access This article is licensed under a Creative Commons Attribution 4.0 International License, which permits use, sharing, adaptation, distribution and reproduction in any medium or format, as long as you give appropriate credit to the original author(s) and the source, provide a link to the Creative Commons licence, and indicate if changes were made. The images or other third party material in this article are included in the article's Creative Commons licence, unless indicated otherwise in a credit line to the material. If material is not included in the article's Creative Commons licence and your intended use is not permitted by statutory regulation or exceeds the permitted use, you will need to obtain permission directly from the copyright holder. To view a copy of this licence, visit http://creativecommons.org/licenses/by/4.0/.

\section{Appendix}

\section{See Table 7}


Table 7 Description of variables

\begin{tabular}{|c|c|}
\hline Variable & Description \\
\hline Sales level (log) & Log of the amount of sales in the last FY before the survey (thousands of US\$) \\
\hline Growing sales & Dummy variable taking the value of 1 if the sales were growing, and 0 otherwise \\
\hline Firm has female owner(s) & Dummy variable taking the value of 1 if the firm has female owner(s), and 0 otherwise \\
\hline Firm has top female manager & Dummy variable taking the value of 1 if the firm has female top manager, and 0 otherwise \\
\hline Firm size & Number of employees \\
\hline Firm age & Age of business (years) \\
\hline Experience of top manager & Experience of the top manager in the sector (years) \\
\hline Firm is an exporter $(Y=1, N=0)$ & $\begin{array}{l}\text { Dummy variable taking the value of } 1 \text { if the firm exports some of its products, and } 0 \text { other- } \\
\text { wise }\end{array}$ \\
\hline Firm is part of a large firm $(Y=1, N=0)$ & Dummy variable taking the value of 1 if the firm is part of a large business, and 0 otherwise \\
\hline Lack of skilled workers is obstacle $(\mathrm{Y}=1, \mathrm{~N}=0)$ & $\begin{array}{l}\text { Dummy variable taking the value of } 1 \text { if the firm perceives the lack of skilled workers as an } \\
\text { impediment, and } 0 \text { otherwise }\end{array}$ \\
\hline Firm operates in manufacturing $(Y=1, N=0)$ & $\begin{array}{l}\text { Dummy variable taking the value of } 1 \text { if the firm operates in the manufacturing sector, and } 0 \\
\text { otherwise }\end{array}$ \\
\hline Internal funds & $\%$ of working capital funded from internal funds \\
\hline Local banks & $\%$ of working capital funded by local banks \\
\hline Overdraft facility & Dummy variable taking the value of 1 if the firm has an overdraft facility, and 0 otherwise \\
\hline Land ownership & Dummy variable taking the value of 1 if the firm owns the land it occupies, and 0 otherwise \\
\hline Lack of land ownership is obstacle $(\mathrm{Y}=1, \mathrm{~N}=0)$ & $\begin{array}{l}\text { Dummy variable taking the value of } 1 \text { if the firm perceives the lack of land ownership as an } \\
\text { impediment, and } 0 \text { otherwise }\end{array}$ \\
\hline Eswatini & Dummy variable taking the value of 1 if the firm operates in Eswatini, and 0 otherwise \\
\hline Lesotho & Dummy variable taking the value of 1 if the firm operates in Lesotho, and 0 otherwise \\
\hline
\end{tabular}

\section{References}

Aghion, P., Fally, T., \& Scarpetta, S. (2007). Credit constraints as a barrier to the entry and post-entry growth of firms. Economic Policy, 22(52), 733-779.

Aidis, R., \& Estrin, S. (2014). Institutions, incentives and entrepreneurship. In Z. Acs, L Szerb and E Autio (eds.), The Global Entrepreneurship and Development Index 213. Cheltenham: Edward Elgar Publishing.

Amin, M. (2010). Gender and firm size: Evidence from Africa. Economics Bulletin, 30(1), 663-668.

Asiedu, E., Kalonda-Kanyama, I., Ndikumana, L., \& Nti-Addae, A. (2013). Access to credit by firms in Sub-Saharan Africa: How relevant is the gender gap? American Economic Review, 103(3), 293-297.

Baliamoune-Lutz, M., \& Lutz, S. (2017). Financing and performance of female-owned firms in Middle Eastern and African economies. Working Paper No. 1709, Instituto Complutense de Analisis Economico, Madrid. https://doi.org/10.2139/ssrn.2907977

Baliamoune-Lutz, M., Brixiová, Z., \& Ndikumana, L. (2011). Credit constraints and productive entrepreneurship in Africa. IZA Discussion Paper No. 6193, Political Economy Research Institute, University of Massachusetts at Amherst.

Baumol, W. J. (1990). Entrepreneurship: Productive, unproductive and destructive. Journal of Political Economy, 985(5), 893-921.

Brixiová, Z., \& Kangoye, T. (2016). Gender and constraints to entrepreneurship in Africa: New evidence from Swaziland. Journal of Business Venturing Insights, 5, 1-8.

Brixiová, Z., \& Kangoye, T. (2019). Networks, start-up capital and women's entrepreneurial performance in Africa: Evidence from Eswatini. In A. Bullough, D. Hechavarria, C.G. Brush \&
L.F. Edelman (Eds.), High-growth women's entrepreneurship: Programs, policies and practices. Cheltenham: Edward Elgar Publishing.

Brixiová, Z., \& Kiyotaki, N. (1997). Private sector development in transition economies. Carnegie-Rochester Conference Series on Public Policy, 46, 241-279.

Cetrulo, A., Cirrillo, V., \& Guarascio, D. (2019). Weaker jobs, weaker innovation. Exploring the effects of temporary employment on new products. Applied Economics. https://doi.org/10.1080/00036 846.2019.1619015.

Chaudhuri, K., Sasidharan, S., \& Raj, R. S. N. (2019). Gender, small firm ownership and credit access: Some insights from India. Small Business Economics. https://doi.org/10.1007/s11187-018-0124-3.

Cragg, J. C., \& Donald, S. G. (1993). Testing identifiability and specification in instrumental variable models. Econometric Theory, 9, 222-240.

Derera, E., Chitakunye, P., \& O'Neill, C. (2014). The impact of gender on start-up capital: A case of women entrepreneurs in South Africa. The Journal of Entrepreneurship, 23(1), 95-114.

Dieterich, C., Huang, A., \& Thomas, A. (2016). Women's opportunities and challenges in Sub-Saharan African job markets. IMF Working Paper No. WP/116/118.

Djankov, S., Miguel, E., Qian, Y., Roland, G., \& Zhuravskaya, E. (2005). Who are Russia's entrepreneurs? Journal of the European Economic Association, 3, 587-597.

Fowowe, B. (2017). Access to finance and firm performance: Evidence from African countries. Review of Development Finance, 7(1), $6-17$.

Gartner, W. B. (1990). What are we talking about when we talk about entrepreneurship? Journal of Business Venturing, 5, 15-28. 
Hakura, D., Hussain, M., Newiak, M., Thakkor, M., \& Yang, F. (2016). Inequality, gender gaps and economic growth: Comparative evidence for Sub-Saharan Africa. IMF Working Paper WP/16/111.

Hallward-Driemeier, M. (2013). Enterprising women: Expanding economic opportunities in Africa. Washington, DC: World Bank.

Kanbur, R. (1980). A note on risk taking, entrepreneurship, and Schumpeter. History of Political Economy, 12(4), 489-498.

Kanbur, S. M. R. (1982). Entrepreneurial risk taking, inequality, and public policy: An application of inequality decomposition analysis to the general equilibrium effects of progressive taxation. Journal of Political Economy, 90(1), 1-21.

Kihlstrom, R. E., \& Laffont, J. J. (1979). A general equilibrium entrepreneurial theory of firm formation based on risk aversion. Journal of Political Economy, 87, 719-848.

Kirzner, I. M. (1973). Competition and entrepreneurship. Chicago: University of Chicago Press.

Knight, F. H. (1921). Risk, uncertainty and profit. New York: Houghton Mifflin.

Kristiansen, S. (2004). Social networks and business success: The role of sub-cultures in an African context. American Journal of Economics and Sociology, 63(5), 1149-1172.

Lazaer, E. P. (2005). Entrepreneurship. Journal of Labor Economics, 23(4), 649-680.

Li, W. (1998). Government loan, guarantee and grant programs: An evaluation. Federal Reserve Bank of Richmond Economic Quarterly, 84(4), 25-51.

Malapit, H. J. L. (2012). Are women more likely to be credit constrained? Evidence from low income urban households in the Philippines. Feminist Economics, 18(3), 81-108.

Mordi, C., Simpson, R., Singh, S., \& Okafor, C. (2010). The role of cultural values in understanding the challenges faced by female entrepreneurs in Nigeria. Gender in Management, 25(1), 5-21.

Nelson, J. (2015). Are women really more risk-averse than men? A re-analysis of the literature using expanded methods. Journal of Economic Surveys, 29(3), 566-585.

Nieman, G., \& Nieuwenhuizen, C. (2014). Entrepreneurship: A South African perspective. Pretoria: Van Schaik.

Ostry, J. D., Alvarez, J., Espinoza, R. A., \& Papageorgiou, C. (2018). Economic gains from gender inclusion: New mechanisms, new evidence. IMF Staff Discussion Note (October 8).

Quartey, P., Turkson, E., Abor, J. Y., \& Iddrisu, A. M. (2017). Financing the growth of SMEs in Africa: What are the constraints to SME financing within ECOWAS? Review of Development Finance, 7(1), 18-28.

Renzulli, L. A., Aldrich, H., \& Moody, J. (2000). Family matters: Gender, networks and entrepreneurial outcomes. Social Forces, 79(2), 523-546.

Sarder, J. H., Ghosh, D., \& Rosa, P. (1997). The importance of support services to small enterprises in Bangladesh. Journal of Small Business Management, 35(2), 26-36.

Schumpeter, J. A. (1934). The theory of economic development: an inquiry into profits, capital, credit, interest and the business cycle. Harvard Economic Studies (Vol. 46). Cambridge, MA: Harvard College.
Singh, G., \& Belwal, R. (2008). Entrepreneurship and SMEs in Ethiopia. Gender in Management, 23(2), 120-136.

Verheul, I., \& Thurik, R. (2001). Start-up capital: Does gender matter? Small Business Economics, 16(4), 329-345.

Wengel, J., \& Rodriguez, E. (2006). SME export performance in Indonesia after the crisis. Small Business Economics, 26, 25-37.

Wynarczyk, P., \& Watson, R. (2005). Firm growth and supply chain partnership: An empirical analysis of UK SME subcontractors. Small Business Economics, 24, 39-51.

Publisher's Note Springer Nature remains neutral with regard to jurisdictional claims in published maps and institutional affiliations.

Zuzana Brixiová is an Associate Professor at the University of Economics in Prague. She is also an Adjunct Associate Professor at the School of Economics, University of Cape Town, Senior Researcher at the Technical University of Ostrava, and a Research Fellow at the Institute of Labor Economics (IZA). Previously, she worked for the IMF, OECD, as well as in Africa as Advisor to the Chief Economist and Vice President of the African Development Bank and Economic Advisor at the UNDP Eswatini. She was also a Fulbright scholar at the Addis Ababa University. Her current research interests are in the areas of labor economics, development economics, and public finance. She holds a Ph.D. in Economics from the University of Minnesota and Ing. (M.A.) in Finance from the University of Economics in Prague.

Thierry Kangoye is a Principal Strategy and Policy Officer at the African Development Bank Group. His research interests include financial inclusion, financial sector development, gender, entrepreneurship, and infrastructure development. He has also worked on issues related to development finance, private investments, and banking, private sector development capacity building initiatives in various multilateral organizations such as the United Nations Economic Commission for Africa (UNECA), the United Nations Industrial Development Organization (UNIDO) and the World Bank Group. He holds a Ph.D. in development economics from the Clermont School of Economics (University of Auvergne, France).

Fiona Tregenna holds the DST/NRF South African Research Chair in Industrial Development and is a Professor of Economics at the University of Johannesburg. She has previously worked for universities in South Africa and abroad, sits on high-level economic advisory bodies, and has consulted for international organizations such as UNIDO, UNCTAD, and the ILO. Her primary research interest is in issues of structural change and industrial development. She has received several research awards and major grants and is currently Principal Investigator in a two-year project on Innovation and Inclusive Industrialization. Tregenna holds a Ph.D. in Economics from the University of Cambridge. 